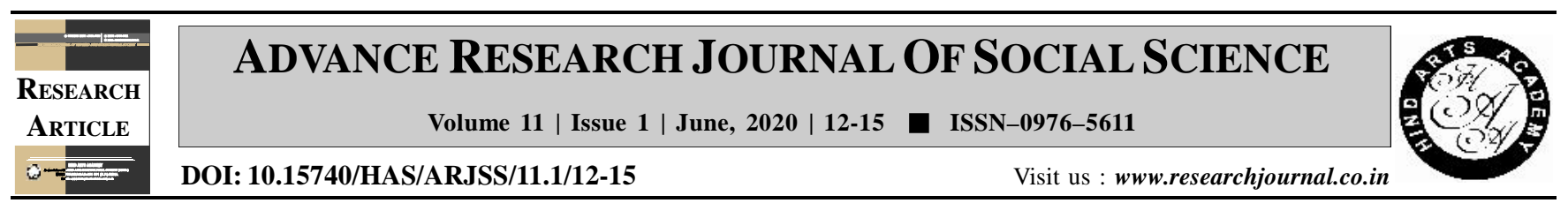

\title{
Attitude scale construction to measure the attitude of extension personnel towards farm women
}

Poree Saikia*, Manju Dutta Das and Manoshi Baruah Deka

Department of Extension and Communication Management, College of Home Science, Assam Agricultural University, Jorhat (Assam) India

(Email : poreesaikia@gmail.com,ppp.aau@gmail.com and manoshibdeka@gmail.com )

\section{ARTICLE INFO :}

$\begin{array}{lll}\text { Received } & : & 31.10 .2019 \\ \text { Revised } & : & 20.04 .2020 \\ \text { Accepted } & : & 16.05 .2020\end{array}$

KEY WORDS :

Attitude, Extension personnel,

Farm women

\section{HOW TO CITE THIS ARTICLE :}

Saikia, Poree, Das, Manju Dutta and Deka, Manoshi Baruah (2020). Attitude scale construction to measure the attitude of extension personnel towards farm women. Adv. Res. J. Soc. Sci., 11 (1): $12-$ 15, DOI: 10.15740/HAS/ARJSS/11.1/ 12-15.Copyright@2020:Hind AgriHorticultural Society

*Author for correspondence

\begin{abstract}
A scale was developed to measure the attitude of the extension personnel towards farm women based on Likert's technique. A list of 60 statements indicating the positive or negative attitude was drafted suited to the area of study. The statements were edited in the light of 14 criteria enunciated by Edwards (1969). The score of each individual item on the scale was calculated by summing up the weights of the individual items. On the basis of total score, 25 per cent of the subjects with the highest total score and also 25 per cent of the subjects with lowest total scores were taken assuming that these groups provided criterion groups in terms of high and low evaluated by the individual statement. In order to find out the discriminating index for each item, ' $t$ ' value was calculated using the formula and procedure given by Edwards (1969). The scale so developed finally consisted of 10 statements (5 positive and 5 negative) whose ' $t$ ' values were found to be significant at one per cent level of probability.
\end{abstract}

